\title{
Association of chicken growth hormone polymorphisms with egg production
}

\author{
Y.J. Su ${ }^{1 *}$, J.T. Shu ${ }^{1 *}$, M. Zhang ${ }^{1}$, X.Y. Zhang ${ }^{1}$, Y.J. Shan ${ }^{1}$, G.H. Li ${ }^{1}$, \\ J.M. Yin ${ }^{1}$, W.T. Song ${ }^{1}$, H.F. Li ${ }^{1}$ and G.P. Zhao ${ }^{2}$ \\ ${ }^{1}$ Institute of Poultry Science, Chinese Academy of Agricultural Sciences, \\ Yangzhou, China \\ ${ }^{2}$ Institute for Animal Sciences, \\ Chinese Academy of Agricultural Sciences, Beijing, China \\ *These authors contributed equally to this study. \\ Corresponding author: G.P. Zhao \\ E-mail: 674828897@qq.com / 317234683@qq.com
}

Genet. Mol. Res. 13 (3): 4893-4903 (2014)

Received April 8, 2013

Accepted November 21, 2013

Published July 4, 2014

DOI http://dx.doi.org/10.4238/2014.July.4.3

\begin{abstract}
Growth hormone (GH) has diverse functions in animals, together with other hormones from the somatotropic axis. Here, chicken $\mathrm{GH}(\mathrm{cGH})$ was investigated in recessive white chickens and Qingyuan partridge chickens as a candidate gene affecting egg production traits. Chicken egg production traits were studied in association with 4 selected single nucleotide polymorphisms (T185G, G662A, T3094C, and C3199T). Genotyping was performed by the polymerase chain reaction-ligase detection reaction method. $\mathrm{T} 185 \mathrm{G}$ was significantly associated with the egg production traits of body weight at first egg (BW), egg weight at first egg (EW), and the total egg production of 300-day old birds (EN 300). T3094C was also significantly associated with certain egg production traits; however, it affected the 2 breeds differently. Haplotypes of the 4 single nucleotide polymorphisms were also significantly associated with egg production traits of chicken age at first egg laying, BW, EW, and EN 300. H1H6 was the most advantageous diplotype for egg production. We putatively concluded
\end{abstract}


that polymorphisms in the cGH gene and its haplotypes could be used as potential molecular markers for egg production traits to enhance the breeding programs of indigenous chickens.

Key words: Growth hormone gene; Ligase detection reaction; Chicken; Polymorphism; Egg production

\section{INTRODUCTION}

With its long history of animal husbandry and diversified geographical conditions, China has a wide variety of indigenous poultry resources. For instance, there are 108 native chicken breeds in China (Chen et al., 2004). The majority of these chickens are composed of local and fancy breeds characterized by medium to low performance. The Qingyuan partridge chicken represents an important indigenous breed found in Qingyuan City, China. It is a light-bodytype breed with good meat quality, and is renowned for its 3 "yellow", 2 "thin", and 1 "partridge" morphological features, i.e., it has a yellow beak, shanks, and skin; a thin head and bone structure; and partridge feathers. However, the Qingyuan partridge chicken has a relatively slow growth rate, low egg production, and strong incubation behavior, with average annual egg production of 78 (Xu and Chen, 2003). Therefore, breeders are searching for ways to improve these traits to make this species more economically beneficial. The candidate gene approach provides an effectual way to study the quantitative trait loci affecting these traits in chickens.

The growth hormone (GH) axis has a major influence on a diverse array of biological processes, from the cellular level to whole-body phenotypic changes. Evidence for these effects has been provided by the study of transgenic animals, genetic disorders involving genes of the GH axis, and the in vivo and in vitro administration of GH. Chicken growth hormone (cGH) is a polypeptide hormone that is synthesized in and secreted by the pituitary gland. This hormone is involved in a wide variety of physiological functions, such as growth, body composition, egg production, aging, and reproduction. The cGH gene has been assigned to chromosomal G-band region 1q4 (Shaw et al., 1991). The cGH gene contains 5 exons and 4 introns, like that of other mammalian GH genes. However, the cGH gene is significantly larger compared to that of analogous mammalian genes, because of its intron size, which expands it to $3.5 \mathrm{~kb}$ (Tanaka et al., 1992). Studies of White Leghorn and meat-type chickens using restriction fragment length polymorphism (RFLP) have shown that the GH gene is highly polymorphic in the intron region. In addition, alleles were identified that were involved in the selection of a series of egg layers for egg production and in the selection of the size of the abdominal fat pad in broilers (Fotouhi et al., 1993; Kuhnlein and Zadworny, 1994). Mou et al. (1995) reported the presence of $2 \mathrm{Msp}$ I sites in chicken intron 1, with 1 MspI RFLP being established. Kuhnlein et al. (1997) analyzed 12 noninbred strains of White Leghorn chicken by PCR-RFLP at $3 \mathrm{MspI}$ sites (PM1, PM2, and PM3) and $1 \mathrm{SacI}$ site (PS1). These polymorphic sites were located in intron 1, intron 3, and intron 4, respectively. The authors suggested that the alleles that were located within the introns might have been selected for several reasons, such as an array of egg production traits, resistance to Marek's disease, or resistance to avian leukosis (Kuhnlein et al., 1997; Feng et al., 1997). Nie et al. (2005) used denaturing high-performance liquid chromatography to investigate 4 chicken breeds, and identified 283 SNPs from 12 genes of the somatotropic axis that differed in growth and reproductive characteristics. Of these, 
46 SNPs were detected in the GH gene and MspI-RFLP in intron 1 had a G662A mutation, while 2 Msp I-RFLPs in intron 4 had T3094C and C3199T mutations. The authors also found a T185G mutation in the 5'-UTR (the SNP location was based on the published cGH gene sequence: GenBank accession No. AY461843).

In the present study, we describe a new, sensitive assay for the detection of the GH gene, based on polymerase chain reaction-ligase detection reaction (PCR-LDR). LDR was originally developed to discriminate single-base mutations and polymorphisms (Barany and Gelfand, 1991). This technique utilizes the ability of DNA ligase to preferentially seal adjacent oligonucleotides hybridized to target DNA, in which there is perfect complementation at the nick junction (e.g., a missing phosphodiester bond).

In this study, PCR-LDR was used to genotype 4 previously reported polymorphisms of the cGH gene (T185G, G662A, T3094C, and C3199T; Nie et al., 2005) for 2 chicken breeds in China, Recessive white and Qingyuan partridge chicken. We aimed to evaluate the genetic effects of variation in the GH gene on the egg production and reproduction traits of these 2 chicken breeds. The results are anticipated to generate potential molecular markers for egg production and reproduction traits that might be used to enhance the breeding programs of Qingyuan partridge chickens.

\section{MATERIAL AND METHODS}

\section{Experimental animals}

Blood samples of 136 Recessive White (RW) chickens and 187 Qingyuan partridge (QY) chickens were randomly collected from the National Gene Pool for Indigenous Chicken Breeds (Yangzhou, China) and Guangdong Tiannong Food Co. Ltd. (Guangzhou, China), respectively. All birds were housed in a stacked cage rearing system, with 1 cage for each bird. Hens were fed a commercial corn-soy-bean-based diet with $16.5 \%$ crude protein and 2650 $\mathrm{kcal} / \mathrm{kg}$ maintenance energy, and had free access to feed and water. The house was automatically ventilated, to maintain an ambient temperature of between $20^{\circ}$ and $28^{\circ} \mathrm{C}$, with a $16-\mathrm{h}$ light/day photoperiod at 15 lux. A number of parameters were documented for both breeds, including the age at first egg (AFE), total egg production at 300 days of age (EN 300), body weight at first egg (BW), and egg weight at first egg (EW). All procedures involving animals were approved by the Animal Care and Use Committee at the Institute for Animal Sciences (IAS), Chinese Academy of Agricultural Sciences (CAAS), where the experiment was conducted. All experimental procedures were performed according to authorization granted by the Chinese Ministry of Agriculture.

\section{DNA extraction and PCR amplification}

DNA was extracted from whole blood samples using the Purgene DNA Isolation Kit (Gentra Systems, Inc., Minneapolis, MN, USA). Three pairs of primers were designed to amplify the fragments, including the 4 mutations, according to the genomic sequence of the $\mathrm{cGH}$ gene in the GenBank database (accession No. AY461843). The primer sequences and PCR product information are presented in Table 1. 
Table 1. Sequences and PCR conditions of each pair of primers.

\begin{tabular}{llc}
\hline Primers & Sequence of the primer & Length of the product $(\mathrm{bp})$ \\
\hline GH 185-up & 5'-AAAACCAGGCAGGAAAATCA-3' & 195 \\
GH 185-low & 5'-TACGGAGATGGAAAGGTTGG-3' & \\
GH 662-up & 5'-GGTGATGGGATACGATGGTG-3' & 169 \\
GH 662-low & 5'-CCCTGTCAAGGTTAGGCTCA-3' & 56 \\
GH 3094-3199-up & 5'-ATGCCACATGAGTCTGGACA-3' & 245 \\
GH 3094-3199-low & 5'-CAGCACGGTTGTGTTGGA-3' & 56 \\
\hline
\end{tabular}

PCR was carried out in $20 \mu \mathrm{L} 50 \mathrm{ng}$ genomic DNA, $5 \mathrm{pM}$ primer mixture, $20 \mathrm{mM}$ of each dNTP, $100 \mathrm{mM} \mathrm{Mg}^{2+}, 5 \mathrm{X}$ Q-Solution, and $5 \mathrm{U} / \mu \mathrm{L}$ Taq DNA polymerase. The amplification protocol had an initial denaturation and enzyme activation phase at $95^{\circ} \mathrm{C}$ for $15 \mathrm{~min}$, followed by 35 cycles of denaturation at $94^{\circ} \mathrm{C}$ for $30 \mathrm{~s}$, annealing at $56^{\circ} \mathrm{C}$ for $1 \mathrm{~min}$, extension at $72^{\circ} \mathrm{C}$ for $1 \mathrm{~min}$, and then a final extension at $72^{\circ} \mathrm{C}$ for $7 \mathrm{~min}$. PCR products were checked on $3 \%$ agarose gel that had been stained with ethidium bromide (Ligase detection reaction).

\section{Ligase detection reaction}

Three probes were designed for each SNP; 1 common probe and 2 discriminating probes for the 2 types of the allele (Table 2). The common probe anneals to the PCR-amplified template that is positioned immediately downstream of the nucleotide in question. The common probes contained a phosphate in the 5'-terminal position and a 6-carboxyfluorescein (FAM) fluorophore at the 3 '-end. At one end of the 3 '-terminal position, the allelic probe contains the nucleotide corresponding to the wild-type allele. At the other end of the 3 '-terminal position, the allelic probe contains nucleotide corresponding to the variant allele that is present. These 2 allelic probes compete to anneal to the template adjacent to the common probe. This generates a double-stranded region containing a nick (e.g., a missing phosphodiester bond) at the nucleotide position, which requires testing. Only the allelic probe with perfect complementation to the template is ligated to the common probe by the DNA ligase.

Table 2. Probe sequences of LDR.

\begin{tabular}{ll}
\hline Probe name & Probe sequences $\left(5^{\prime}-3^{\prime}\right)$ \\
\hline GH T185G_modify & P-CGCAGGTAGAAAATCCACCTGATTTTTTTTTTTTTTTTTTTTTTTTTTTTTTT-FAM \\
GH T185G_T & TTTTTTTTTTTTTTTTTTTTTTTTTTTTGTGCTTACGTGGGGGAATTTCTCA \\
GH T185G_G & TTTTTTTTTTTTTTTTTTTTTTTTGTGCTTACGTGGGGGAATTTCTCC \\
GH G662A_modify & P-GGCTCTGCGTGTGTCAGCCCACCACTTTTTTTTTTTTTTTTTTT-FAM \\
GH G662A_G & TTTTTTTTTTTTTTTTTTTTTTAGTTGCCACATTTTAGTTCAGAGCC \\
GH G662A_A & TTTTTTTTTTTTTTTTTTTTAGTTGCCACATTTTAGTTCAGAGCT \\
GH T3094C_modify & P-GGCCTGGCTTTTCTAGTTATTTAGGTTTTTTTTTTTTTTTTTTTTTTTTTTT-FAM \\
GH T3094C_T & TTTTTTTTTTTTTTTTTTTTTTTTTTTTAGGACGGAGGGTTTGTTTGCTCCCA \\
GH T3094C_C & TTTTTTTTTTTTTTTTTTTTTTTTTTTTTAGGACGGAGGGTTTGTTGCTCCCG \\
GH C3199T_modify & P-GCTCAAACTGCCCAGGGCTCCATCCTTTTTTTTTTTTTTTTTTTTTTT-FAM \\
GH C3199T__C & TTTTTTTTTTTTTTTTTTTTTTTTTTTGCCATGGGCTGGGTGCCCCCCACCG \\
GH C3199T_T & TTTTTTTTTTTTTTTTTTTTTTTTTTTTTGCCATGGGCTGGGTGCCCCCCACCA \\
\hline
\end{tabular}

LDRs were carried out in a $10-\mu \mathrm{L}$ mixture containing $1 \mu \mathrm{L}$ buffer, $1 \mu \mathrm{L}$ Probe Mix, $0.05 \mu \mathrm{L}$ Taq DNA ligase (New England Biolabs, USA), $1 \mu \mathrm{L}$ PCR product, and $6.95 \mu \mathrm{L}$ de- 
ionized water. The reaction program had an initial heating at $94^{\circ} \mathrm{C}$ for $2 \mathrm{~min}$, followed by 35 cycles of $30 \mathrm{~s}$ at $94^{\circ} \mathrm{C}$, and $2 \mathrm{~min}$ at $60^{\circ} \mathrm{C}$.

Reactions were stopped by chilling the tubes in an ethanol-dry ice bath, and adding $0.5 \mathrm{~mL}$ of $0.5 \mathrm{mM}$ EDTA. Aliquots of $1 \mu \mathrm{L}$ of the reaction products were mixed with $1 \mu \mathrm{L}$ loading buffer ( $83 \%$ formamide, $8.3 \mathrm{mM}$ EDTA, and $0.17 \%$ Blue Dextran) and $1 \mu \mathrm{L}$ ABI GS500 Rox-Fluorescent molecular weight marker. This mixture was denatured at $95^{\circ} \mathrm{C}$ for $2 \mathrm{~min}$, and then chilled rapidly on ice before loading it on a $5 \mathrm{M}$ urea-5\% polyacrylamide gel. It was then electrophoresed on an ABI 3100 DNA sequencer (Applied Biosystems, USA) at 3000 V. Fluorescent ligation products were analyzed and quantified using the ABI Gene Scan 672 software (Applied Biosystems).

\section{Sequencing}

To confirm the accuracy of the PCR-LDR genotyping method, direct DNA sequencing of randomly selected PCR products was performed. The percentage of the sequencing samples was about $5 \%$. The results of the PCR-LDR genotyping showed $100 \%$ conformity with the direct DNA sequencing of the randomly selected PCR products.

\section{Statistical analyses}

Haplotypes were inferred by the PHASE 2.0 software (http://www.stat.washington. edu/stephens/software.html). Association analysis of single polymorphisms or haplotypes with egg production was determined by ANOVA, using general linear model and type III sums of squares performed by the SAS 9.0 software (http://www.sas.com/software/sas9/). The model used was $\mathrm{Y}_{\mathrm{ij}}=\mu+\mathrm{B}_{\mathrm{i}}+\mathrm{G}_{\mathrm{j}}+\mathrm{e}_{\mathrm{ij}}$, where $Y_{i j}$ is the observed traits, $\mu$ is the overall population mean, $B_{i}$ is the effect of breed, $G_{j}$ is the effect of genotype, and the $e_{i j}$ is the residual error. All values are reported as least square means \pm standard error of mean (SE). The minimum haplotype frequency was set at $2 \%$.

\section{RESULTS}

\section{Characteristics of the study population}

A total of $136 \mathrm{RW}$ and 187 QY chickens were used in this study. The characteristics of these 2 breeds are summarized in Table 3. Significanty differences were found between RW chickens and QY chickens $(\mathrm{P}<0.01)$.

\begin{tabular}{|c|c|c|c|c|c|}
\hline Breed & No. & AFE (days) & BW (g) & EW (g) & EN 300 \\
\hline QY & 187 & $164.45 \pm 0.51^{\mathrm{A}}$ & $1613.97 \pm 9.42^{\mathrm{A}}$ & $35.62 \pm 0.20^{\mathrm{A}}$ & $88.36 \pm 1.18^{\mathrm{A}}$ \\
\hline RW & 136 & $175.40 \pm 0.79^{\mathrm{B}}$ & $2336.99 \pm 19.02^{\mathrm{B}}$ & $38.69 \pm 0.38^{\mathrm{B}}$ & $102.48 \pm 2.00^{\mathrm{B}}$ \\
\hline
\end{tabular}

$\mathrm{A}, \mathrm{B}$ Means within a column with no common superscript differ highly significantly $(\mathrm{P}<0.01)$. QY $=$ Qingyuan Partridge chicken; RW = Recessive White chicken; AFE = age at first egg; EN $300=$ total egg production at 300 days of age; $\mathrm{BW}=$ body weight at first egg; $\mathrm{EW}=$ egg weight at first egg. 


\section{Genotype and haplotype inference}

The electrophoretic profiles of the PCR-LDR analysis of T185G, G662A, T3094C, and C3199T site are shown in Figures 1-4.
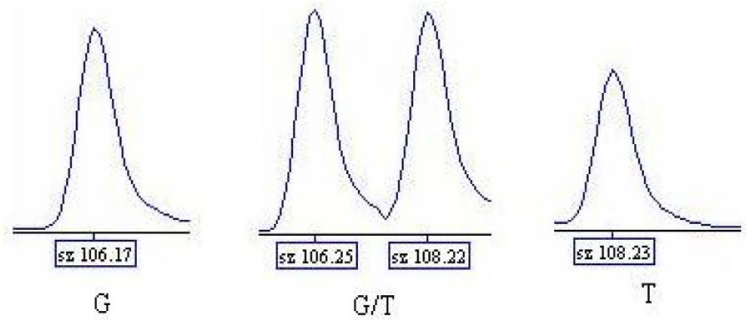

Figure 1. Genotype result of GH T185G.

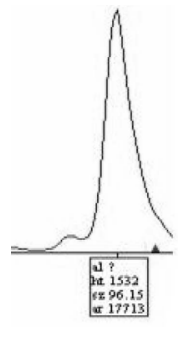

Figure 2. Genotype result of GH G662A.

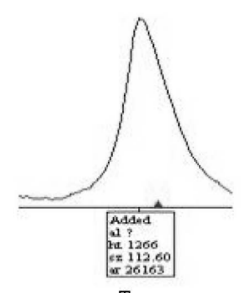

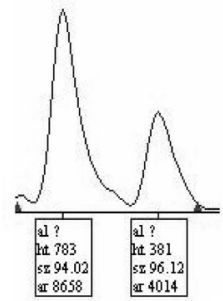

$\mathrm{A} / \mathrm{G}$

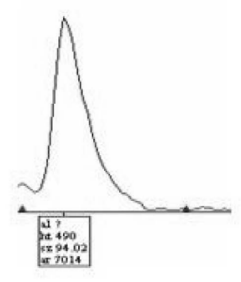

A

Figure 3. Genotype result of GH T3094C.
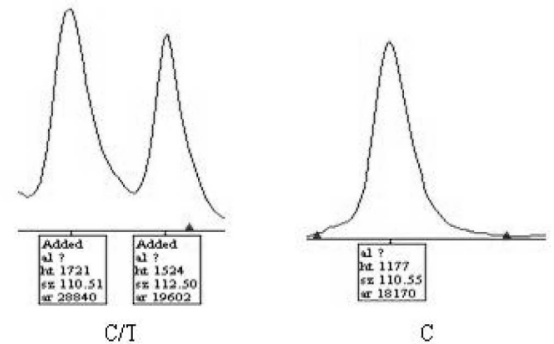

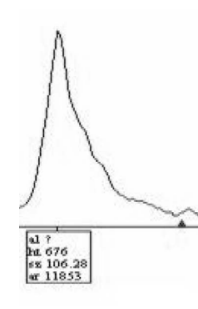

C

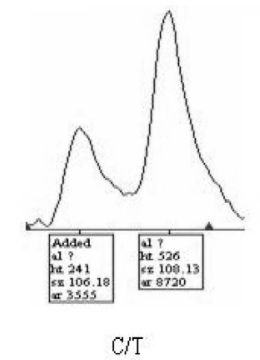

$\mathrm{ClT}$

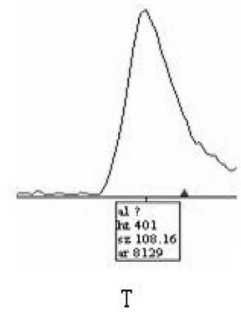

CFUNPEC-RP www.funpecrp.com.br 
Three genotypes were found at each site. Highly significant differences in allelic frequencies were found for all 4 SNPs between QY chickens and RW chickens (Table 4).

\begin{tabular}{|c|c|c|c|c|c|c|c|c|}
\hline \multirow[t]{2}{*}{ Breed } & \multicolumn{2}{|c|}{185} & \multicolumn{2}{|c|}{662} & \multicolumn{2}{|c|}{3094} & \multicolumn{2}{|c|}{3199} \\
\hline & $\mathrm{T}$ & G & G & A & $\mathrm{T}$ & $\mathrm{C}$ & $\mathrm{C}$ & $\mathrm{T}$ \\
\hline$\overline{\mathrm{QY}}$ & 0.951 & 0.049 & 0.287 & 0.713 & 0.122 & 0.878 & 0.831 & 0.169 \\
\hline RW & 0.812 & 0.188 & 0.435 & 0.565 & 0.200 & 0.800 & 0.713 & 0.287 \\
\hline$\chi^{2}$ & 33.83 & & 13.91 & & 9.48 & & 12.78 & \\
\hline
\end{tabular}

Haplotypes that were constructed based on the 4 SNPs and their frequencies in the 2 breeds are shown in Table 5. A total of 13 haplotypes were found, of which 2 were major [H1 (TACC, 35.6\%) and H5 (TGCC, 27.5\%)], 3 were intermediate [H2 (TACT, 8.8\%), H3 (TATC, 9.2\%), and H6 (TGCT, 6.3\%)], 4 were minor [H4 (TATT, 2.3\%), H7 (GACC, 2.8\%), $\mathrm{H} 8$ (GATC, 2.3\%), and $\mathrm{H} 9$ (GACT, 3.3\%)], and 4 were rare [H10-H13, with frequencies of $<1 \%]$. H4 was the unique haplotype of QY chickens, while H9 was the unique haplotype of RW chickens.

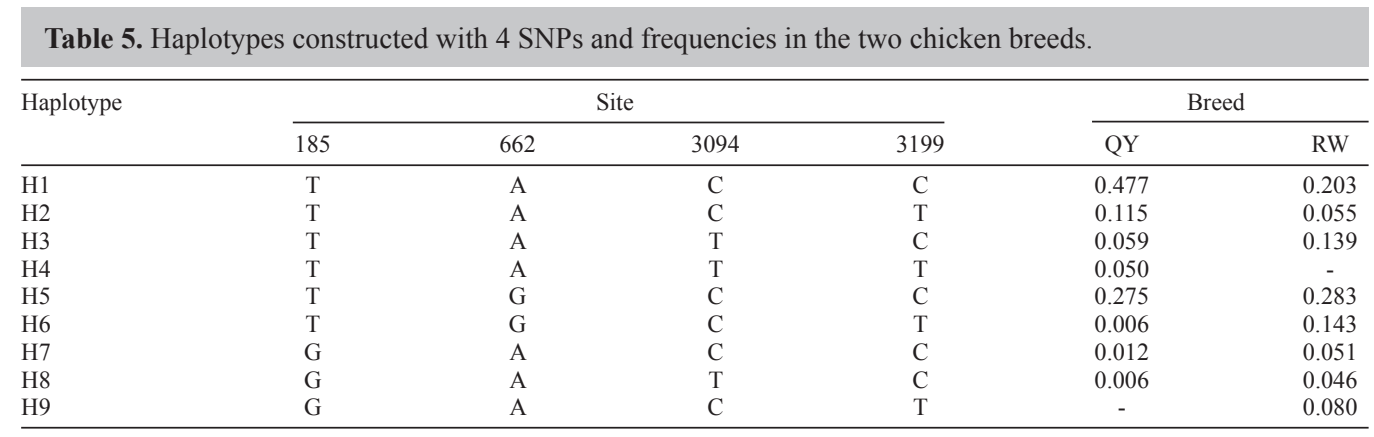

\section{Association of specific SNPs with chicken egg production traits}

Statistical analyses were performed to test the significance of the difference of breed effect, genotype effect, and the interaction between the genotype effect and the breed effect among the 3 genotypes of the 4 loci. The results showed that significant breed effect $(\mathrm{P}<0.05)$ existed in the 4 polymorphic loci; hence, we analyzed the genotypic effect within each breed. However, only significant genotypic effects were found at the T185G and T3094C sites in both chicken breeds (Table 6 ). At the $\mathrm{T} 185 \mathrm{G}$ site, GG genotype birds had significantly higher BW and EW compared to TG and TT genotype birds. In comparison, the differences between individuals with TG and TT genotypes were not significant in either breed. The T185G site was also significantly associated with chicken EN $300(\mathrm{P}<0.05)$. TG genotype birds had significantly higher EN 300 compared to GG and TT genotype QY chickens. In comparison, both TG and TT genotype RW chickens had significantly higher EN 300 compared to GG 
genotype birds. No significant association was found for the T185G site with AFE traits in either chicken breed. The T3094C site was significantly associated with AFE traits in QY chickens $(\mathrm{P}<0.05)$, in which TT genotype birds had significantly later AFE compared to TC and $\mathrm{CC}$ genotype birds. There was no significant difference between TC and CC genotypes. However, no significant association was found for this site with AFE traits in RW chickens. In RW chickens, the T3094C site was significantly associated with BW and EN 300 traits, in which TT genotype birds had significantly higher BW compared to TC and CC genotype birds, while CC genotype birds had significantly higher EN 300 compared to TC and TT genotype individuals.

Table 6. Association of GH genotypes with egg production traits in the two chicken breeds.

\begin{tabular}{|c|c|c|c|c|c|c|c|c|c|}
\hline \multirow[t]{2}{*}{ Site } & \multirow[t]{2}{*}{ Genotype } & \multicolumn{4}{|c|}{ QY } & \multicolumn{4}{|c|}{ RW } \\
\hline & & AFE (days) & BW (g) & EW (g) & EN 300 & AFE (days) & BW (g) & EW (g) & EN 300 \\
\hline \multirow[t]{3}{*}{185} & TT & $165.6=$ & $1602.7 \pm 19.6^{\mathrm{a}}$ & $35.5 \pm 0.4^{\mathrm{a}}$ & $87.9 \pm 2.6^{\mathrm{a}}$ & $175.9 \pm 1.4$ & $2323.4 \pm 33.8^{\mathrm{a}}$ & $37.9 \pm 0.7^{\mathrm{a}}$ & 103.2 \\
\hline & TG & $164.5 \pm 2.6$ & $1554.9 \pm 49.2^{\mathrm{a}}$ & $35.1 \pm 1.0^{\mathrm{a}}$ & $98.0 \pm 6.6^{b}$ & $176.8 \pm 2.2$ & $2273.3 \pm 52.9^{\mathrm{a}}$ & $38.6 \pm 1.1^{\mathrm{a}}$ & $104.6 \pm 5.5^{\mathrm{a}}$ \\
\hline & GG & $167.0 \pm 6.7$ & $1740.0 \pm 65.8^{\mathrm{b}}$ & $41.8 \pm 1.6^{\mathrm{b}}$ & $85.0 \pm 6.7^{\mathrm{a}}$ & $180.7 \pm 3.5$ & $2404.4 \pm 85.1^{b}$ & $41.6 \pm 1.0^{\mathrm{b}}$ & $85.4 \pm 4.9^{b}$ \\
\hline \multirow[t]{3}{*}{3094} & $\mathrm{TT}$ & $171.3 \pm 3.8^{\mathrm{a}}$ & $\mathrm{v} 1584.3 \pm 32.6$ & $35.6 \pm 1.5$ & $91.3 \pm 9.7$ & $179.0 \pm 6.3$ & $2650.0 \pm 152.2^{\mathrm{a}}$ & $38.4 \pm 0.8$ & $94.5 \pm 5.2^{\mathrm{a}}$ \\
\hline & $\mathrm{TC}$ & $164.6 \pm 1.8^{b}$ & $1615.8 \pm 34.1$ & $35.6 \pm 0.7$ & $90.0 \pm 4.6$ & $176.1 \pm 1.7$ & $2339.2 \pm 40.9^{b}$ & $38.7 \pm 0.9$ & $91.7 \pm 4.3^{\mathrm{a}}$ \\
\hline & $\mathrm{CC}$ & $163.9 \pm 1.3^{\mathrm{b}}$ & $1618.8 \pm 23.8$ & $35.8 \pm 0.5$ & $89.4 \pm 3.1$ & $177.5 \pm 1.5$ & $2264.3 \pm 36.9^{b}$ & $38.6 \pm 0.8$ & $108.3 \pm 3.9^{b}$ \\
\hline
\end{tabular}

a,b Means within a column among same site with no common superscript differ significantly $(\mathrm{P}<0.01)$. QY $=$ Qingyuan Partridge chicken; RW = Recessive White chicken; AFE = age at first egg; EN $300=$ total egg production at 300 days of age; $\mathrm{BW}=$ body weight at first egg; $\mathrm{EW}=$ egg weight at first egg.

\section{Association of the haplotypes with chicken egg production traits}

The diplotypes with a frequency of more than $2 \%$ were used in the association analysis; hence, a total of 289 individuals with 11 diplotypes $(53 \mathrm{H} 1 \mathrm{H} 1,38 \mathrm{H} 1 \mathrm{H} 2,24 \mathrm{H} 1 \mathrm{H} 3,6$ $\mathrm{H} 1 \mathrm{H} 4,65 \mathrm{H} 1 \mathrm{H} 5,15 \mathrm{H} 1 \mathrm{H} 6,6 \mathrm{H} 2 \mathrm{H} 5,30 \mathrm{H} 3 \mathrm{H} 5,28 \mathrm{H} 5 \mathrm{H} 5,15 \mathrm{H} 5 \mathrm{H} 6$, and 9 H5H9) were used in the association analysis (Table 7). The haplotypes were significantly associated with the egg production traits of AFE, BW, EW, and EN 300. Among the 11 diplotypes, H1H6 had a higher value for AFE, BW, EW, and EN 300 compared to the other diplotypes. In comparison, H1H4 had a relatively lower value for AFE, BW, EW, and EN 300 compared to the other diplotypes.

\begin{tabular}{|c|c|c|c|c|}
\hline \multirow[t]{2}{*}{ Diplotypes } & \multicolumn{4}{|c|}{ Traits } \\
\hline & AFE (days) & BW (g) & EW (g) & EN 300 \\
\hline $\mathrm{H} 1 \mathrm{H} 1$ & $166.3 \pm 1.3^{\mathrm{a}}$ & $1713.8 \pm 49.8^{\mathrm{a}}$ & $36.5 \pm 0.6^{\mathrm{ab}}$ & $90.3 \pm 2.9^{\mathrm{a}}$ \\
\hline $\mathrm{H} 1 \mathrm{H} 2$ & $166.3 \pm 1.6^{\mathrm{a}}$ & $1769.0 \pm 62.8^{\mathrm{a}}$ & $36.3 \pm 0.7^{\mathrm{ab}}$ & $90.2 \pm 3.7^{\mathrm{a}}$ \\
\hline H1H3 & $170.8 \pm 2.3^{\mathrm{a}}$ & $2105.7 \pm 90.5^{b}$ & $37.1 \pm 1.1^{\mathrm{ab}}$ & $94.2 \pm 5.4^{\mathrm{a}}$ \\
\hline $\mathrm{H} 1 \mathrm{H} 4$ & $162.8 \pm 3.5^{\mathrm{a}}$ & $1650.7 \pm 133.3^{\mathrm{a}}$ & $34.1 \pm 1.6^{\mathrm{b}}$ & $87.3 \pm 5.8^{\mathrm{a}}$ \\
\hline H1H5 & $166.6 \pm 1.2^{\mathrm{a}}$ & $1808.3 \pm 44.4^{\mathrm{a}}$ & $36.7 \pm 0.5^{\mathrm{ab}}$ & $91.8 \pm 2.6^{\mathrm{a}}$ \\
\hline H1H6 & $177.1 \pm 2.7^{\mathrm{b}}$ & $2435.0 \pm 103.2^{\mathrm{b}}$ & $38.6 \pm 1.2^{\mathrm{a}}$ & $104.6 \pm 6.1^{b}$ \\
\hline $\mathrm{H} 2 \mathrm{H} 5$ & $165.0 \pm 3.4^{\mathrm{a}}$ & $1665.5 \pm 133.3^{\mathrm{a}}$ & $36.4 \pm 1.6^{\mathrm{ab}}$ & $88.7 \pm 3.8^{\mathrm{a}}$ \\
\hline H3H5 & $172.1 \pm 1.7^{\mathrm{b}}$ & $2025.0 \pm 65.3^{b}$ & $37.9 \pm 0.8^{\mathrm{a}}$ & $90.2 \pm 3.8^{\mathrm{a}}$ \\
\hline H5H5 & $167.6 \pm 1.9^{\mathrm{a}}$ & $1874.1 \pm 74.9^{\mathrm{a}}$ & $36.1 \pm 0.9^{\mathrm{ab}}$ & $90.4 \pm 4.4^{\mathrm{a}}$ \\
\hline H5H6 & $171.5 \pm 2.6^{\mathrm{a}}$ & $2186.9 \pm 98.4^{b}$ & $38.3 \pm 1.1^{\mathrm{a}}$ & $113.1 \pm 5.8^{\mathrm{b}}$ \\
\hline H5H8 & $173.5 \pm 3.2^{\mathrm{b}}$ & $2337.5 \pm 163.3^{b}$ & $39.2 \pm 1.9^{\mathrm{a}}$ & $86.0 \pm 9.7^{\mathrm{a}}$ \\
\hline H5H9 & $173.2 \pm 2.8^{\mathrm{b}}$ & $2300.0 \pm 108.8^{\mathrm{b}}$ & $37.1 \pm 1.3^{\mathrm{ab}}$ & $113.9 \pm 6.4^{b}$ \\
\hline
\end{tabular}

a,b Means within a line with no common superscript differ significantly $(\mathrm{P}<0.05)$. AFE = age at first egg; EN $300=$ total egg production at 300 days of age; $\mathrm{BW}=$ body weight at first egg; $\mathrm{EW}=$ egg weight at first egg. 


\section{DISCUSSION}

Egg production is an important economic parameter in poultry systems. Endocrine factors (Kim et al., 2004) and many environment factors such, as photoperiod length and feeding allowances, potentially influence egg production (Liu et al., 2004; Lewis and Gous, 2006). However, ultimately, the genetic makeup of a species has a fundamental influence on egg production. It is known that the genes of the growth axis are important in the regulation of growth, development, and differentiation. In addition, the role of the GH in reproduction has been described as being "more akin to fine tuning than that of a major player..." (OgilvyStuart and Shalet, 1992). However, experimental studies indicate that this statement underestimates the importance of GH in reproductive function. This is because GH modulates steroidogenesis, gametogenesis, and gonadal differentiation, as well as gonadotrophin secretion and responsiveness (Zachmann, 1992). Many polymorphisms have been identified in the GH gene of farm animals, including pigs (Kirkpatrick and Huff, 1991; Franco et al., 2005), bovine (Lucy et al., 1993; Grochowska et al., 2001), and goat (Malveiro et al., 2001). Compared to other animals, the intron regions of the cGH gene is highly polymorphic. Furthermore, studies using RFLP have shown that these polymorphisms are associated with abdominal fat, egg production, resistance to Marek's disease or avian leucosis, and meat yield traits (Fotouhi et al., 1993; Kuhnlein et al., 1997; Feng et al., 1997; Yan et al., 2003; Lei et al., 2007; Zhang et al., 2007; Xu et al., 2011).

In the present study, we describe the development of a new mutation detection method for cGH based on PCR-LDR, which is a highly sensitive and quantitative technique. A distinguishing feature of PCR-LDR is that misligations do not undergo subsequent amplification; therefore, the chance of false-positive reactions is reduced. Any low-level polymerase errors remain unselected, and so only contribute minimal background noise. PCR-LDR has been used in the detection of some viruses, oncogenes, and tumor-suppressor genes (Khanna et al., 1999; Rondini et al., 2008). The results showed that all of the egg production traits were significantly different between RW chickens and QY chickens, indicating that these 2 breeds might have different genetic backgrounds. The genotyping results were concordant to direct DNA sequencing, indicating the accuracy of the PCR-LDR method. The allele frequency distributions of all 4 SNPs tested were highly significant $(\mathrm{P}<0.01)$ between QY chickens and RW chickens. This result indicates that the 2 breeds have different genetic backgrounds. Mutations in the promoter region might cause change to the transcription factor binding sites, consequently affecting transcription and phenotype characteristics (Xu et al., 2005). The association analysis indicated the presence of significant associations for both breeds between $\mathrm{T} 185 \mathrm{G}$ genotypes of the GH gene and the egg production traits of BW, EW, and EN 300. The genetic effects of this mutation were coincident in populations with different genetic backgrounds; hence, there might be a relationship between this SNP site and the egg production traits of chickens. The T3094C site was also significantly associated with certain egg production traits; however, this site had a different effect on each breed. For instance, T3094C was only significantly associated with AFE in QY chickens, but was significantly associated with BW and EN 300 traits in RW chickens. Therefore, further study is required to clarify the effect of T3094C genotypes.

Because of the abundance of SNP and the limited power of conventional single-site analyses, haplotype analysis has received increasing focus for the mapping of complex-disease genes (Cardon and Abecasis, 2003; Lin, 2004). The H1H6 diplotype was found to be more associated with egg production compared to other haplotype combinations. In contrast, the 
H1H4 diplotype caused lower egg production, while the H4 (TATT) haplotype was unique to Qingyuan partridge chickens. Therefore, $\mathrm{H} 1$ might represent the most advantageous haplotype for enhancing egg production, whereas H4 is probably a disadvantage haplotype for egg production.

\section{CONCLUSIONS}

This study confirmed that polymorphisms of the GH gene and their haplotypes are associated with chicken egg production traits. The H1 haplotype could be potentially used as a marker to enhance egg production traits.

\section{ACKNOWLEDGMENTS}

Research supported by the project of the National Key Technology R\&D Program (\#2011BAD28B03), the National Natural Science Foundation of China (\#31301967), the Earmarked Fund for Modern Agro-Industry Technology Research System, the National High Technology Research and Development Program “863” (\#2011AA100301, \#2011AA100305), and the Natural Science Foundation of Jiangsu Province (\#BK2012268).

\section{REFERENCES}

Barany F and Gelfand DH (1991). Cloning, overexpression and nucleotide sequence of a thermostable DNA ligaseencoding gene. Gene 109: 1-11.

Cardon LR and Abecasis GR (2003). Using haplotype blocks to map human complex trait loci. Trends Genet. 19: 135-140.

Chen GH, Wang KH, Wang JY, Ding C, et al. (2004). Poultry Genetic Resources in China. 1st edn. Shanghai Scientific and Technological Press, Shanghai.

Feng XP, Kuhnlein U, Aggrey SE, Gavora JS, et al. (1997). Trait association of genetic markers in the growth hormone and the growth hormone receptor gene in a White Leghorn strain. Poult. Sci. 76: 1770-1775.

Fotouhi N, Karatzas CN, Kuhnlein U and Zadworny D (1993). Identification of growth hormone DNA polymorphisms which respond to divergent selection for abdominal fat content in chickens. Theor. Appl. Genet. 85: 931-936.

Franco MM, Antunes RC, Silva HD and Goulart LR (2005). Association of PIT1, GH and GHRH polymorphisms with performance and carcass traits in Landrace pigs. J. Appl. Genet. 46: 195-200.

Grochowska R, Sorensen P, Zwierzchowski L, Snochowski M, et al. (2001). Genetic variation in stimulated GH release and in IGF-I of young dairy cattle and their associations with the leucine/valine polymorphism in the GH gene. $J$. Anim. Sci. 79: 470-476.

Khanna M, Park P, Zirvi M, Cao W, et al. (1999). Multiplex PCR/LDR for detection of K-ras mutations in primary colon tumors. Oncogene 18: 27-38.

Kim MH, Seo DS and Ko Y (2004). Relationship between egg productivity and insulin-like growth factor-I genotypes in Korean native Ogol chickens. Poult. Sci. 83: 1203-1208.

Kirkpatrick BW and Huff BM (1991). Detection of insertion polymorphisms in $5^{\prime}$ flank and second intron of the porcine growth hormone gene. Anim. Genet. 22: 192-193.

Kuhnlein U and Zadworny D (1994). Disease Resistance Genetics: Selection at the DNA Level. Proceedings of the 5th World Congress on Genetics Applied to Livestock Production, Guelph, 249-256.

Kuhnlein U, Ni L, Weigend S, Gavora JS, et al. (1997). DNA polymorphisms in the chicken growth hormone gene: response to selection for disease resistance and association with egg production. Anim. Genet. 28: 116-123.

Lei M, Luo C, Peng X, Fang M, et al. (2007). Polymorphism of growth-correlated genes associated with fatness and muscle fiber traits in chickens. Poult. Sci. 86: 835-842.

Lewis PD and Gous RM (2006). Effect of final photoperiod and twenty-week body weight on sexual maturity and early egg production in broiler breeders. Poult. Sci. 85: 377-383.

Lin DY (2004). Haplotype-based association analysis in cohort studies of unrelated individuals. Genet. Epidemiol. 26: 255-264. 
Liu HK, Lilburn MS, Koyyeri B, Anderson JW, et al. (2004). Preovulatory surge patterns of luteinizing hormone, progesterone, and estradiol-17beta in broiler breeder hens fed ad libitum or restricted fed. Poult. Sci. 83: 823-829.

Lucy MC, Hauser SD, Eppard PJ, Krivi GG, et al. (1993). Variants of somatotropin in cattle: gene frequencies in major dairy breeds and associated milk production. Domest. Anim. Endocrinol. 10: 325-333.

Malveiro E, Pereira M, Marques PX, Santos IC, et al. (2001). Polymorphisms at the five exons of the growth hormone gene in the Algarvia goat: possible association with milk traits. Small Rumin. Res. 41: 163-170.

Mou L, Liu N, Zadworny D, Chalifour L, et al. (1995). Presence of all additional Pst I fragment in intron 1 of the chicken growth hormone-encoding gene. Gene 160: 313-314.

Nie Q, Lei M, Ouyang J, Zeng H, et al. (2005). Identification and characterization of single nucleotide polymorphisms in 12 chicken growth-correlated genes by denaturing high performance liquid chromatography. Genet. Sel. Evol. 37 : 339-360.

Ogilvy-Stuart AL and Shalet SM (1992). Commentary: Growth hormone and puberty. J. Endocrinol. 135: 405-406.

Rondini S, Pingle MR, Das S, Tesh R, et al. (2008). Development of multiplex PCR-ligase detection reaction assay for detection of West Nile virus. J. Clin. Microbiol. 46: 2269-2279.

Shaw EM, Shoffner RN, Foster DN and Guise KS (1991). Mapping of the growth hormone gene by in situ hybridization to chicken chromosome 1. J. Hered. 82: 505-508.

Tanaka M, Hosokawa Y, Watahiki M and Nakashima K (1992). Structure of the chicken growth hormone-encoding gene and its promoter region. Gene 112: 235-239.

$\mathrm{Xu}$ GF and Chen KW (2003). Photograph Album of China Indigenous Poultry Breeds. China Agricultural Press, Beijing, 40-41.

Xu H, Gregory SG, Hauser ER, Stenger JE, et al. (2005). SNPselector: a web tool for selecting SNPs for genetic association studies. Bioinformatics. 21: 4181-4186.

Xu HP, Zeng H, Zhang DX, Jia XL, et al. (2011). Polymorphisms associated with egg number at 300 days of age in chickens. Genet. Mol. Res. 10: 2279-2289.

Yan B, Deng X, Fei Q, Hu X, et al. (2003). Association between single nucleotide polymorphisms of the chicken growth hormone gene and chicken growth and carcass traits. Chin. Sci. Bull. 48: 1304-1307.

Zachmann M (1992). Interrelations between growth hormone and sex hormones: physiology and therapeutic consequences. Horm. Res. 38 (Suppl 1): 1-8.

Zhang XL, Jiang X, Liu YP, Du HR, et al. (2007). Identification of Avai polymorphisms in the third intron of GH gene and their associations with abdominal fat in chickens. Poult. Sci. 86: 1079-1083. 